Conference

Circuit

\title{
New technologies and new forms of cooperation
}

\author{
By Lester J. Pourciau
}

\section{A report on the Crimea '97 Conference}

$\mathbf{T}$ he title above is actually the subtitle of the Fourth International Conference on Libraries and Associations in the Transient World, the Crimea 97 Conference held in Sudak in the Autonomous Republic of Crimea, Ukraine, from June 7-15, 1997. More than 200 presentations were made over a five-day period within the organizational context of sulsject sections and 12 topical workshops.

The opening session, somewhat more elaborate and formal than anything experienced or observed in the U.S., was followed by a plenary session at which eight presenters set the tone for much of what was to follow during the week. Among these, Victor Montviloff of the UNESCO General Information Programme in Paris spoke of UNESCO library programs today. He outlined the various efforts made by UNESCO to promote libraries and librarianship throughout Eastern Europe, emphá-

\section{Current economic conditions in Ukraine often force unpopular decisions about libraries, including the reduction of their hours of operation.}

opment in Georgia," presented by Nina $\mathrm{T}$ Chkhenkeli, of the American Center of Information Resources (USIS Thilisi), Thilisi, Georgia. Chkhenkeli discussed a current awareness document supply service created by the Library Automation Association in Georgia and the National Libraty of Georgià. This service is a document supply system for documents published in Georgia and includes not only the traditional functions of inquiry, searching, locating, ordering, copying/scanning, and delivery, but also what is a popular service in Georgia, Books by Mail, which provides books published in Georgia to users. At the time of her writing and presentation, there was no provision for foreign document supply services, with the exception of traditional interlibrary loan and international book exchange programs. Chkhenkeli discussed at some length the problems associated with the relatively small geographic size of Georgia, sizing that interlibrary cooperation was a prime focus and that, with the increasing use of computers and the Internet, "the ethical use of such technology is a major factor in UNESCO's library programs."

Because of the large number of presentations made throughout the week, no individual person could attend all, and thus one hact to pick and choose among those of interest. Several of interest to this writer occurred within the section on "World Wide Information Infrastructure: General Problems of Library Cooperation." Among these was a paper, "On the Prospects of Document Supply Service Devel-

the economic conditions in Georgia, and the number of users ready to pay for information services. She judged the number of users to be insufficient to make feasible the creation of an independent enterprise for the delivery of books published anywhere other than in Georgia, and speculated that the "introduction of a fee-based service for delivering articles from foreign periodicals could in time become a solution and a natural development of symbiosis between the National Library of Georgia and the Library Association in Georgia."

Among the various discussions of library cooperation was a presentation by Emilija 
Banionyte, director of the Vilnius Pedagogical University Library. Banionyte spoke of and described the various cooperative efforts initiated by Lithuanian lilsraries after the declaration of that country's independence in 1990. She described a variety of cooperative endeavors between Lithuanian libraries and other libraries, especially those in Nordic countries. She identified the Lithuanian Librarians Association as being the most active group in Lithuania in creating and maintaining international contacts as well as carrying out general library development projects.

speaking to a problem that is common throughout the former Soviet Inion, Elena K. Aleksandrova of the National Parliamentary Library of Ukraine in Kiev spoke on "Ukrainian Libraries in the Legal Environment." Aleksandrova discussed the progress and clevelopment in Ukraine of a legal infrastructure appropriate for a relatively new independent state and indicated that some 900 separate legislative acts have been approved. Libraries in Ukraline are under the direct or indirect jurisdiction of some 20 different, recently enacted laws. In general. these laws ensure the rights of citizens to access information via libraries.

\section{PROVE Y OUR POINT}

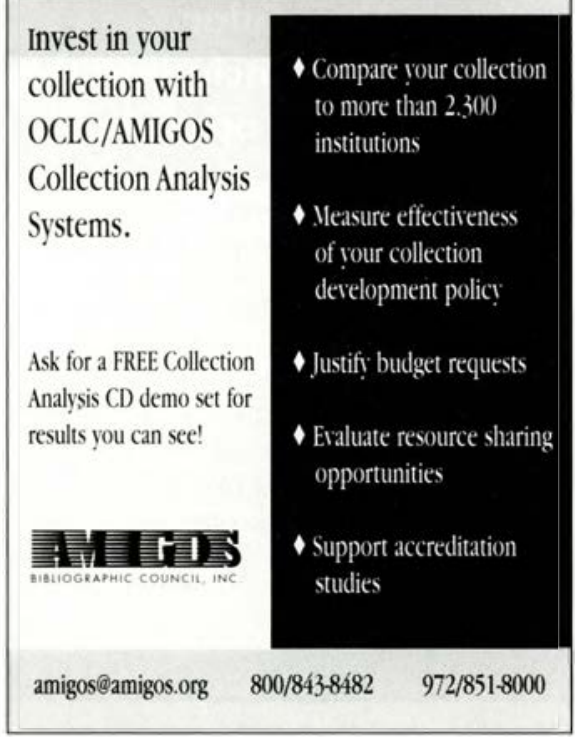

Nevertheless, there are a number of laws that seemingly allow for variant interpretation, and some aspects of library activities and services are not reflected in the approved legislation. Further, some executive aspects of the laws are in clispute. Aleksandrova also pointed out that current economic conditions in Ukraline often force unpopular decisions about libraries, including the reduction of their hours of operation, the transfer of library staff to parttime employment, and, in some cases, the closing of libraries.

The foregoing are but a few examples of the wide variety of presentations made at Crimea 97 about libraries and their conditions in Eastern Europe. It is clear to those who have attended previous Crimea conferences that great progress has been and continues to be made. Nevertheless, there is a large measure of work to be done throughout the Former Soviet Union to standardize procedures, to enhance interlibrary cooperation, and to extend services to all citizens. Crimea ' 97 was a rewarding experience, both professionally and personally. It is indeed a fascinating experience to meet and to interact with people from a variety of countries and cultural orientations.

\section{(Faculty use conl. from page 553)}

made much progress in pooling Web expertise on campus, coordinating support, and providing a forum for sharing ideas about instructional use of the Web. Attenclance at workshops and brown bags is good, faculty are adding pages to the college's Wel server, and more classes are using the Web as a regular part of their work.

While it is too early to make any final assessment of the team's effectiveness in providing support to faculty, for the library; the team has already achieved its secondary goal of keeping librarians involved in campus Web activities. By serving as a central location for the teams's activities - workshops and brown bags are held in the library - the library is able to demonstrate its interest and involvement with the Web. By collaborating with other team members, librarians broaden their own Web skills. And, most important, by being under the aegis of the team, librarians' efforts to support the Web are now more visible and reach more people. 